\title{
Educational Reforms as Correlates of Principals' Administrative Effectiveness in Public Secondary Schools in AkwaIbom State, Nigeria
}

\author{
Scholastica C. O. Ekere*, Udeme Etim Akpan \\ Department of Educational Management, Faculty of Education, University of Calabar, P.M.B 1115, Calabar, Cross River State, \\ Nigeria.
}

How to cite this paper: Scholastica C. O Ekere, Udeme Etim Akpan. (2021). Educational Reforms as Correlates of Principals Administrative Effectiveness in Public Secondary Schools in Akwalbom State, Nigeria. The Educational Review, USA, 5(8), 301-308.

DOI: 10.26855/er.2021.08.007

Received: July 23, 2021

Accepted: August 16, 2021

Published: August 27, 2021

Corresponding author: Scholastica C. O. Ekere, Department of Educational Management, Faculty of Education, University of Calabar, P.M.B 1115, Calabar, Cross River State, Nigeria.

Email: scottekere@gmail.com

\begin{abstract}
The study was designed to examine educational reforms as correlates of principals' administrative effectiveness in public secondary schools in Akwalbom State, Nigeria. Two hypotheses were formulated and tested. Correlational research design was adopted for the study. Literature was reviewed based on the sub-variables used for the study. The population and sample of the study comprised 236 principals' of 236 public secondary schools. Two sets of instruments were developed for data collection by the researcher named: "Educational Reforms Questionnaire (ERQ)" which contained twenty-four (24) items and "Principals' Administrative Effectiveness Questionnaire (PAEQ)” which contained eighteen (18) items respectively. The instruments were validated by three experts in Measurement and Evaluation through validity. A reliability test was conducted on the variables to obtain a reliability coefficient which ranged from $0.82-0.91$ for educational reforms questionnaire and $0.75-0.83$ and 0.72 respectively for principals; administrative questionnaire using Cronbach Alpha method. The data collected were subjected to statistical analysis using Pearson Product Moment Correlation at the 0.05 level of significance. The results of the analysis revealed a positive significant relationship between information and communication and technology and entrepreneurship education on principals' administrative effectiveness. Based on the findings of the study, it was recommended among other things that government should ensure through monitoring that principals' fully key into the reform process to deliver the mandatory goods.
\end{abstract}

\section{Keywords}

Educational Reforms, Principal, Administrative Effectiveness and Secondary School

\section{Introduction}

Educational reforms in any given country of which Nigeria is not exclusive always originate through the basic belief that substantial improvement can be gained in a country and by its persons via a careful development of the academic process (Omolewa, 2007). Although there have been efforts in the past at reforming education even though the clause "reform" may not have been used. Nigeria has seen numerous scholastic reforms which commenced at the pre-independence. The change was burnout of the nation's notable protesters for self-rule that led the British expatriates to modify the learning system in operation in 1954 from 8-6-2-3 system, i.e., 8-year primary, 6-year secondary, 2-year 
higher school certificate and 3-year university to a new system of 6-5-2-3 that is 6-year primary, 5-year secondary, 2-year higher school certificate and 3-year university. The alteration occasioned in lessening the number of years at the primary and secondary school stages and created further awareness in the minds of her citizenries about education.

The major reform programmes in education after independence was the Universal Primary Education (UPE) programmes and the 6-3-3-4 system of education. The first two decades after the nation's independence was seen as an era of self-determination and expansion in education, Fafunwa (1974). Other foremost change guidelines include: the Federal Government overthrow of provincial universities in 1975 (Adamu, 2004); the Universal Basic Education Programme of 1999, among others. Similarly, learning reformations have been carried out by both advanced, developing and the under-developed countries of the world. Bello (2007) in a statement pointed out certain reasons for reforms in education to include; to have education applicable to the wishes of the country, furnish students with appropriate knowledge, transmute their reserved and specialized lives, make education handy to more persons and pay extra responsiveness to science and technology. Others comprised the plea to: intimate learners with up-to-date information and communication technology skills, kit schools with suitable assets, improve teaching approaches and instructive practices, mend the school valuation system, and prepare the citizens of the country to face the contests of globalization.

Reforms consist of changes and improvement to a law, social system or institution (Atanu, 2006). However, there can be changes without improvements. Innovations and reforms in education are responses to varying economic and social-political circumstances both in developed and developing states. For people to feel the need to change an educational system at any given time, it is obligatory that the novel philosophies and needs which occurred in the previous system are no lengthier germane (Adamu, 2004).

For schools to meet the expected standards, principals must be ready to drive the various reforms initiatives to its target. These reforms may include but not limited to integration of information and communication technology, and introduction of entrepreneurship education. Integration of information and communication technology in the context of this work refers to the incorporation of electronic device to carryout administrative tasks in the school system in a manner that is acceptable, smart and timely. Entrepreneurship education is considered important in this study and refers to a course taught by instructor with the objective of making the learners become independent and self-employed with the ability to take risk and translating the risk into profit making ventures through education.

Principals who are transformational leaders are those whose leadership style inspires extraordinary performance among staff members. Kreiter, Kinicki and Buelens (2002) asserted that transformational leadership can yield momentous syllabus amendment and outcomes; since it fathoms the process of change. It is able to convert staff to chase desired goals in view of self-interest. Reforms in education therefore, need to consider the unique roles of principals in the country's education system. Principals' are seen and regarded as managers in the school system and are expected to direct the affairs of the organization for the achievement of predestined goals and objectives. The success of any nation is inseparable from its sound policy framework which is basically guided and supported with functioning managerial technique, informed by modern decrees.

\section{Literature review}

\subsection{Integration of information and communication technology (ICT) and principals' administrative effectiveness}

The place of information and communication technology (ICT) in education and the world at large cannot be overstated. Globally, contemporary day industries are chatted, piloted and eased through the use of mobiles, fax technologies and computer webs over the internet. Apart from explaining the abridgement, there is no entirely accepted meaning of Information and Communication Technology, which is constantly growing virtually on a daily basis. Yet, quite a lot of scholars have defined ICT in various ways. According to a United Nations Report cited in Kok (2006), ICT encompasses internet services, information technology kit and services, telecommunications equipment and services, mass media and dissemination, libraries and documentation centres, profit-making info providers, network-based information services and other associated information and communication activities.

Ajayi and Ekundayo (2009) examined the use of information and communication Technology (ICT) in Nigerian Secondary Schools with particular references to the degree of handiness of ICT amenities in schools, the ability in using ICT services for teaching-learning, the seeming benefits of using ICT and the ills opposing the use of ICT in secondary schools. Descriptive survey design was used for the study. The population comprised wholly the teachers and principals of the secondary schools in Ondo and Ekiti States. The study sample constituted 320 teachers and 40 principals arbitrarily selected from the two states. A self-designed questionnaire titled "Information and Communication Technology and Secondary Schools Questionnaire (ICTSSQ)" was used to elicit records for the study. Facts collected for the research 
were examined using frequency counts and ratio scores. The study revealed that ICT amenities were deficient in schools and teachers and students were to a little extent, exposed to the use of ICT. Besides, the study revealed the alleged supports of using ICT in schools which include making teaching-learning fascinating; facilitating the distance education programme; aiding teachers to be up-to date, augmenting quality work by both the teachers and the students.

Conversely, in the face of these observed benefits, the work also revealed some of the defies facing ICT in secondary schools as: Uneven power source, poor computer literate teachers; exorbitant price of procuring computers in schools; scarce amenities to support full application of ICT and dearth of funds. It was therefore suggested that government should offer intermittent training for teachers on computer and ICT skills acquisition.

Yusuf, Maina and Dare (2013) explored the accessibility, utilization and management of ICT facilities in teaching English Language in secondary schools in Kaduna State, Nigeria. The study made use of descriptive survey research design. A questionnaire tagged "Availability, Utilization and Management of Information and Communication Technology in Teaching English Language in Secondary Schools (AUMICTSS)" was used for data collection. Twenty secondary schools were accidentally selected from Kaduna Metropolis. One hundred teachers participated by answering to the items on the questionnaire. The records collected were analyzed using proportions and ratios. The findings revealed a shortage of ICT amenities in secondary schools in Kaduna as there are only very few of such facilities as the management of these facilities need training and re-training. It was recommended that government as a matter of sincerity should provide more ICT facilities in schools and guarantee the provision of electricity in every school for possible deployment of these facilities. Tutors should equally be trained and re-trained regularly in the use and management of ICT facilities for effective English Language curriculum delivery.

Bua, Olatunde and Amough (2013) surveyed the effect of administrative hurdles on the management of secondary schools in Zone 'A' Education District of Benue State, Nigeria. Two research questions and hypotheses were postulated to guide the study. Ex-post facto survey design was adopted. Five hundred and ten (510) teachers from 17 grant aided secondary schools formed the sample. A structured 10-item of a 4-point Likert rating scale questionnaire titled "Administrative Problems Questionnaire (APQ)" was constructed by the researcher and used for data collection. Data gotten were analyzed using descriptive and inferential statistics. Mean and standard deviation were used to analyze the research questions while the chi-square $\left(\mathrm{X}^{2}\right)$ test of goodness of fit was used to test the hypotheses. The findings revealed that there was a significant consequence of population explosion of students and information and communication technology on the management of secondary schools. It was recommended based that in order to solve the problem of population explosion, more teachers, classes and hostel accommodation in schools be constructed and adaptability of up-to-date ICT facilities for the advantage of the school.

Okon, Ekaette and Ameh (2015) studied the correlation between information and communication technology deployment and principals' administrative effectiveness in public secondary schools in Akwalbom State, Nigeria. Two hypotheses were put forward to guide the study. An ex-post facto research design was employed in the study. Three hundred and forty-eight (348) principals as well as their vice principals constituted the population of the study in AkwaIbom State. Purposive sampling technique was adopted to draw a sample of two hundred and fifty five (255) principals from eighty-five (85) schools. Two self-developed questionnaires tagged "Information and Communication Technology Utilization Questionnaire (ICTUQ)” and "Principals’ Administrative Effectiveness Questionnaire (PAEQ)” was used for data collection. The outcome of the study revealed a significant correlation between ICT usage in communication method and record keeping, and principals' administrative effectiveness. It was acclaimed that government should recognize ICT-compliant proprietors in order to prompt others in the use of ICT for more effective administrative ends.

\subsection{Entrepreneurship education and principals' administrative effectiveness}

There is a wide spread of believe that entrepreneurship education in the phase of this harsh economic situation would make a significant contribution to improving the entrepreneurship orientation of people, leading to the acquisition of skills, creativity, confidence, drive and courage in order to create employment for self and others. Entrepreneurship education in the words of Isaac, Viscera, Fredrick and Brijlal (2007) is the purpose intervention by educator in the life of the learner to survive in the world of business; and it has as its focus an action orientation primarily embodied in teaching students how to develop a business plan.

Entrepreneurship education according to Postigo and Tomborini (2002) develops and stimulates entrepreneurial process, providing all tools necessary for starting up new ventures. Archibong and Bassey (2005) submitted that the goal of entrepreneurship education is intended to empower graduates irrespective of their area of specialization with skills that will enable them to engage in income yielding ventures if there are unable subsumed that exposure of students to entrepreneurship education will incite entrepreneurial drive in students and if properly packaged, can be a positive factor in unprecedented unemployment reduction among students. 
Oghojafor, Kuye, Sulaimon, and Okonji (2009) research study focused on mandatory entrepreneurship course for undergraduate youths in the Nigeria's tertiary institutions. The researchers used structured entrepreneur readiness questionnaire to elicit responses from respondents who were undergraduates. It was hypothesized and found with the aid of test of proportion that entrepreneurship education imparts entrepreneurial skills and attitudes to student as well as favourably disposes them towards establishing their own business. This will empower them to contribute positively toward the nation's economic development. The researchers recommended that the government should provide a more conducive environment in the form of quality infrastructural facilities and startup financial support to consummate this initiative of entrepreneurship education.

Egunsola, Dazala and Daniel (2012) explored entrepreneurship education and attitude of undergraduate students to self-employment intentions. The study adopted a survey design and was based on three major theories namely, cause and effect, Pragmatism and social learning theory of career choice. The population of the study was 5,000 undergraduate students; a sample size of 370 was determined using Taro Yamane's formula for finite population and was drawn using stratified sampling technique. Seven research questions were raised for the study. Data were collected using a structured questionnaire titled "Entrepreneurship Education and Self-Employment Intentions Questionnaire (EESEIQ)". The data collected were analyzed using frequency counts and percentage. The findings of the study revealed that exposure to entrepreneurship education is beneficial, it influenced self-employment intentions of tertiary students; it enriched their knowledge on starting and owing business, and changed their perception about self-employment. It was recommended that entrepreneurship education should be included into the curricula of all educational institutions in Nigeria.

Wahab (2014) conducted a research study to explicate the impact of the Post Graduate Leadership Programme (PGLP) on its relevance as perceived by its graduates. A survey using five point Likert type scale and open-ended questions was administered to a cohort of graduates of the PGLP from 2008 to 2013 to explore their perceptions of the PGLP. Qualitative data were analyzed using thematic approach while SPSS was used to analyze the quantitative data. All data collected were synthesized according to the mixed methods conventions and findings were discussed according to the research questions and pertinent emerging themes. Results of the findings indicated that in general graduates were pleased with the theoretical and practical components of the leadership programmes. However, the findings revealed there is room for improvement as services. The study concluded by elucidating certain recommendations for improvement that in turn can make the leadership programme more relevant to the needs of teachers and aspiring leaders in Fiji and beyond.

Deveci (2016) was interested in determining the perceptions of pre-service science teachers towards the concepts of entrepreneurship and entrepreneurial characteristics and to investigate the perceptions of pre-service science teachers regarding transferring the entrepreneurial characteristics to students. The study was designed as a qualitative study ad a phenomenological research approach was used. A total of 12 pre-service science teachers from grades 5 to 8 participated in the study. Data were gathered through the use of semi-structured interviews. The data were evaluated through both descriptive and content analysis. The results of the findings showed that the perceptions of the 12 pre-service science teachers indicated a limited and inadequate understanding of the concept of entrepreneurship, based on their interviews. From these results, it can be said that there is a need to develop educational content in such a way as to increase pre-service science teachers' knowledge and experience with regard entrepreneurship in science teacher training.

\subsection{Statement of the problem}

Every organization is established with the sole aim of achieving specified goals and objectives. Besides setting up such an organization, the purpose will be futile if ineffective and incompetent hands are made to run the operations of such organizations. Principals' as transformational leaders in the school system are seen as drivers of the vision and mission statement for the achievement of the desired goals and objectives. For this reason, it is imperative that they must be properly oriented and reoriented for the effective discharge of their responsibilities in this regard. Observation by the researcher indicates that some public secondary school principals in Akwalbom have been found to neglect their statutory functions as heads in such areas as absenteeism without prior information, lateness to school, and non-compliance with government policies amongst others. Due to the principals' ineffectiveness, these ill-acts have also manifested in teachers inefficiency, poor communication skill, indiscipline among students and staff, poor maintenance culture on school facilities, poor record keeping as well as haphazard decision-making. These problems have bedeviled the various educational reforms injected by the government to progress the educational system. It is also characterized by the fluctuation of performance of students in public examinations over the years. Consequently, serious debates have made headlines on why the persistent happenings. It is on this premise, that the study raised the question: what is the relationship between educational reforms and principals' administrative effectiveness in AkwaIbom State, Nigeria? 


\subsection{Objectives of the study}

The tenacity of this study is to examine the correlation between educational reforms and principals' administrative effectiveness in AkwaIbom State, Nigeria. In specific terms, this study sought to examine the relationship between:

1) integration of information and communication technology (ICT) and principals' administrative effectiveness, and

2) entrepreneurship education and principals’ administrative effectiveness.

\subsection{Research questions}

The following inquiries were framed to guide the study:

1) To what extent does integration of ICT relate to principals' administrative effectiveness?

2) How does entrepreneurship education relate to principals' administrative effectiveness?

\subsection{Statement of hypotheses}

The sequential null hypotheses were articulated to guide the study:

1) There is no significant correlation between integration of ICT and principals' administrative effectiveness.

2) Entrepreneurship education does not significantly relate with principals' administrative effectiveness.

\section{Methodology}

The study adopted a correlational design. This design is used when a researcher is interested in finding out the relationship between two sets of variables. The population of the study comprised 236 principals of public secondary schools in AkwaIbom State, Nigeria. Census method was deployed since the whole census of subjects was used for the study. The sample comprised 236 principals of public secondary schools in AkwaIbom State, Nigeria. The researchers developed dual sets of instruments to obtain facts for the study, namely: "Educational Reforms Questionnaire (ERQ)" and "Principals' Administrative Effectiveness Questionnaire (PAEQ)". Section A of the instrument was "Educational Reforms Questionnaire (ERQ)" with twenty-four (24) items while Section B of the instrument was "Principals' Administrative Effectiveness Questionnaire (PAEQ)" meant to elicit data from teachers on the effectiveness of their principals and consisting eighteen (18) items. Both instruments were responded using a modified 4-point Likertrating scale, ranging from Strongly Agree (SA), Agree (A), Disagree (D) and Strongly Disagree (SD). Each sub-variable was measured using six (6) items. The instruments were validated by three experts in Measurement and Evaluation through face and content validity. A reliability test was conducted on the variables to obtain a reliability coefficient which ranged from 0.82-0.91 for educational reforms questionnaire and 0.75-0.83 and 0.72 respectively for principals; administrative questionnaire using Cronbach Alpha method. The data collected were subjected to statistical analysis using Pearson Product Moment Correlation at 0.05 level of significance.

\section{Results/Interpretations}

Hypothesis one

The study hypothesis stated that there is no significant correlation between integration of ICT and principals' administrative effectiveness

Table 1. Pearson Product Moment Correlation analysis of the relationship between integration of Information and Communication Technology (ICT) and principals' administrative effectiveness ( $N=232)$

\begin{tabular}{ccccc}
\hline Variables & $\bar{X}$ & SD & Rxy & P-level \\
\hline Integration of ICT $(\mathrm{X})$ & 18.13 & 1.76 & & \\
Maintenance of facilities $\left(\mathrm{Y}_{1}\right)$ & 17.78 & 1.74 & $0.523^{*}$ & 0.000 \\
Interpersonal relationship $\left(\mathrm{Y}_{2}\right)$ & 17.51 & 1.85 & $0.466^{*}$ & 0.000 \\
Decision-making $\left(\mathrm{Y}_{3}\right)$ & 17.92 & 1.85 & $0.532^{*}$ & 0.000 \\
\hline
\end{tabular}

${ }^{*} \mathrm{p}<0.05 ; \mathrm{df}=230$; critical $\mathrm{r}=0.138$

Table 1 showed that the calculated r-values obtained in establishing the relationship between integration of ICT and three aspects of principals' administrative effectiveness are as follows: maintenance of facilities, $r=0.523(p<0.05)$; interpersonal relationship, $r=0.466(p<0.05)$; decision-making, $r=0.532(p<0.05)$. At 0.05 level of significance and 
degree of autonomy 230, the critical r-value is 0.138. All the calculated correlation coefficients (r-values) between the independent variable, integration of ICT and three dimensions of principals' administrative effectiveness are seen to be greater than the critical r-value and their significant values are all less than 0.05 level of significance used in the study. With these results, the null hypothesis which stated that there is no significant relationship between integration of information and communication technology (ICT) and principals' administrative effectiveness is rejected in respect to three aspects of the dependent variable. It was therefore accepted that, there is a significant link between integration of ICT and principals' administrative effectiveness in terms of maintenance of facilities, interpersonal relationship and decision-making.

The further indication is that the correlation coefficients are significant and positive. The positive coefficients show a positive correlation between the variables indicating that increase in the independent variable will bring about increase in the dependent variables. Meanwhile, when integration of ICT in running school affairs increases, it will bring about increase in administrative effectiveness of the principals.

\section{Hypothesis two}

This hypothesis stated that there is no significant relationship between entrepreneurship education and principals' administrative effectiveness.

Table 2. Pearson Product Moment Correlation analysis of the relationship between entrepreneurship education and principals' administrative effectiveness $(\mathrm{N}=232)$

\begin{tabular}{ccccc}
\hline Variables & $\bar{X}$ & SD & rxy & P-level \\
\hline Entrepreneurship education (X) & 17.92 & 1.85 & & \\
Maintenance of facilities (Y1) & 17.78 & 1.74 & $0.280^{*}$ & 0.000 \\
Interpersonal relationship (Y2) & 17.51 & 1.85 & $0.230^{*}$ & 0.000 \\
Decision-making (Y3) & 17.92 & 1.85 & $0.321^{*}$ & 0.000 \\
\hline
\end{tabular}

${ }^{*} \mathrm{p}<0.05 ; \mathrm{df}=230 ;$ critical $\mathrm{r}=0.138$

Table 2 indicated that the calculated r-values obtained in establishing the relationship between entrepreneurship education and three aspects of principals' administrative effectiveness are as follows: maintenance of facilities, $r=0.280$ $(p<0.05)$; interpersonal relationship, $r=0.230(p<0.05)$; decision-making, $r=0.321(p<0.05)$. At 0.05 level of significance and degree of freedom 230, the critical r-value is 0.138. All the calculated correlation coefficients (r-values) between the independent variable, entrepreneurship education and three aspects of principals' administrative effectiveness are seen to be greater than the critical r-value and their significant values are all less than 0.05 level of significance used in the study. With these results, the null hypothesis which stated that entrepreneurship education does not significantly relate with principals' administrative effectiveness is rejected in respect to three aspects of the principals' administrative effectiveness. It was therefore accepted that, entrepreneurship education significantly relate with principals' administrative effectiveness in terms of maintenance of facilities, interpersonal relationship and decision-making.

The further indication was that the correlation coefficients are significant and positive. The positive coefficients show a positive correlation between the variables indicating that increase in the independent variable will bring about increase in the dependent variables. Meanwhile, when there is adequacy in the provision of entrepreneurship education, it will bring about administrative efficiency of the principal in the aspects of maintenance of facilities, interpersonal relationship and decision-making.

\section{Discussion of findings}

The result of hypothesis one shows that there is a significant relationship between information communication and technology and principals' administrative effectiveness. The result of this finding is in congruence with the findings by Yusuf, Maina and Dare (2013) whose study revealed a shortage of ICT amenities in secondary schools in Kaduna as there were only very few of such facilities as the management of these facilities need training and re-training. The findings of this study corroborates with the findings by Bua, Olatunde and Amough (2013) who revealed that there was a significant consequence of population explosion of students and information and communication technology on the management of secondary schools. The finding is also in agreement with the findings by Okon, Ekaette and Ameh (2015) whose study revealed a significant correlation between ICT usage in communication method and record keeping, and principals' administrative effectiveness.

The result of hypothesis two shows that there is a significant relationship between entrepreneurship education and 
principals' administrative effectiveness. The result of this finding is line with the view of Archibong and Bassey (2005) who submitted that the goal of entrepreneurship education is intended to empower graduates irrespective of their area of specialization with skills that will enable them to engage in income yielding ventures. The finding of this study agrees with the findings by Egunsola, Dazala and Daniel (2012) who revealed that exposure to entrepreneurship education is beneficial, it influenced self-employment intentions of tertiary students; it enriched their knowledge on starting and owing business, and changed their perception about self-employment. The result of this study also derive credence from the findings by Oghojafor, Kuye, Sulaimon, and Okonji (2009) entrepreneurship education imparts entrepreneurial skills and attitudes to student as well as favourably disposes them towards establishing their own business. This will empower them to contribute positively toward the nation's economic development.

\section{Conclusion}

Based on the results of the study, it was concluded that educational reforms in terms of information and communication technology and entrepreneurship education has a significant positive relationship with principals' administrative effectiveness in terms of maintenance of facilities, interpersonal relationship and decision-making. This infers that the introduction of novel concepts can go a long way to improve the way and manner at which principals of schools perform their duties and vice versa.

\section{Recommendations}

Based on the findings of the study, it was recommended that:

1) Government should ensure through monitoring that principals' fully key into the reform process to deliver the required goods.

2) Principals' should see the reform process as a medium for actualizing the vision of education rather than a threat to expose their ineffectiveness.

\section{References}

Adamu, A. U. (2004). Educational reforms in Nigeria. [Online]. Retrieved $15^{\text {th }}$ of April, 2004, from http:www.kanoonline.com/publications/educational_reform_in_nigeria.htm.

Ajayi, I. A. and Ekundayo, H. T. (2009). The application of information and communication technology in Nigerian secondary schools. International NGO Journal, 4(5), 281-286.

Archibong, I. A. and Bassey, U. U. (2005). Assuring quality graduate output through entrepreneurial oriented education in Nigeria Universities. Nigeria Journal of Curriculum Studies, 12(3), 18-23.

Atanu, F. H. (2006). Reforms in education for national development in the $21^{\text {st }}$ century. A keynote address presented at the $3^{\text {rd }}$ National conference of the school of education Kogi State College of Education, Ankpa, July 15-21.

Bello, M. Y. (2007). On the need for reforms in the Nigerian education sector. Daily Triumph [Online]. Retrieved $23^{\text {rd }}$ of November, 2007, from http//www.triumph newspapers.com/on25102007.html.

Bua, F. T., Olatunde, H. O., and Amough, C. K. (2013). Effect of administration problems on the management of secondary schools in Zone 'A' Educational District of Benue State, Nigeria. European Journal of Business and Management, 5(9), 47-58.

Deveci, I. (2016). Perceptions and competence of Turkish pre-service science teachers with regard to entrepreneurship. Australian Journal of Teacher Education, 41(5), 15-32.

Egunsola, A. O. E., Dazala, I. U., and Daniel, J. D. (2012). Entrepreneurship education and attitude of undergraduate students to self-employment in Mubi, Adamawa State, Nigeria. Journal of Education Practice, 3(8), 95-102.

Fafunwa, B. (1974). History of education in Nigeria. London: George Allen and Urwin.

Isaac, E., Viscera, K. J., Friedrick, C., and Brijlal, P. (2007). Entrepreneurship education and training at the further education and training level in South Africa. Journal of Education, 27, 613-629.

Kok, A. (2006). ICT Integration into classrooms. European Association of Distance Learning, 2(1), 35-49.

Kreiter, R., Kinicki, A., and Buelens, M. (2002). Organizational behaviour. New York: McGraw-Hill Publishing Co.

Oghojafor, B. E. A., Kuye, O. L., Sulaimon, A. A., and Okonji, P. S. (2009). Empowering Nigerian youths for national economic development: The role of entrepreneurship education. Journal of Research in National Development, 7(2), 1-13.

Okon, J. E., Ekaette, S. O., and Ameh, E. (2015). Information and Communication Technology (ICT) utilization and principals' administrative effectiveness in pubic secondary schools in Akwalbom State, Nigeria. African Educational Research Journal, 3(2), 131-135. 
Omolewa, M. (2007). Education reform in Nigeria. Keynote address, committee of Deans of Nigerian universities, University of Lagos, July 14, 2007.

Postigo, S. and Tomborini, M. F. (2002). Entrepreneurship education in Argentina: The case of San Andres University. Paper presented for Internationalizing Entrepreneurship Education and Training conference (INTENT 2002), Malaysia, July 8-10.

Wahab, A. (2014). Graduates perception of a leadership programme for teachers and aspiring leaders in the south pacific. International Studies in Widening Participation, 1(2), 60-85.

Yusuf, H. O., Maina, B., and Dare, M. O. (2013). Assessment of the availability, utilization and management of ICT facilities in teaching English language in secondary school in Kaduna State, Nigeria. Advances in Language and Literary Studies, 4(1), $1-7$. 